\title{
遺伝的アルゴリズムとラグランジュの未定乗数法を用いた 熱源の最適化手法と運用計画チャートの開発 DEVELOPMENT OF OPTIMIZATION METHOD FOR HEAT SOURCE AND CHART FOR OPERATIONAL DESIGN USING GENETIC ALGORITHM AND LAGRANGE MULTIPLIER
}

\author{
池田 伸太郎*，長 井 達 夫** \\ Shintaro IKEDA and Tatsuo NAGAI
}

\begin{abstract}
Various optimization methods of heat source and operational design have been studied in order to reduce energy consumption in building sector. Some problems, however, remain to be improved. Furthermore, some designers plan building services by empirical laws in general buildings. Even if they plan them by optimum design, it isn't necessarily the most suitable that people who work at operation center operate heat sources. The authors have developed the optimization method of heat source using genetic algorithm and Lagrange multiplier to improve previous studies and have developed chart for operational design. If operators use the chart when they operate heat sources, they can understand easily which to operate heat sources and how much output. The result shows that a program which the authors made can calculate on condition that load factor is continuous, the calculation speed is quicker than the previous study, and chart for operational design is convenient for workers at operation center.
\end{abstract}

Keywords : Genetic Algorithm, Lagrange Multiplier, Chart for Operational Design 遺伝的アルゴリズム，ラグランジュの未定乗数法，運用計画チャート

1. はじめに

地球温暖化防止など環境に関する議論が世界的主題になって久し い昨今、とりわけ日本では従来からの環境保全に加えて東日本大震 災の影響から省エネルギーが国民的関心事になっている。しかしな がら民生部門のエネルギー消費量は増加傾向にあり、一般的オフィ スビルでは建物のエネルギー消費量全体の $31.1 \%$ を空調用熱源が 占めている。そこで、機器を容易に交換することが難しい熱源には 設計段階における省エネルギー化が必要であり、そのための最適化 研究が重要となる。熱源構成や運用計画を最適化する研究はこれま でにも行われており、それらの研究は主に、1)熱源構成の最適化に 関する研究、2) 運用計画の最適化に関する研究、3) 熱源構成と運用 計画の総合的な最適化に関する研究の 3 つに大別される。上記 1)の 研究では、年間総コストを目的関数とし混合整数線形計画法の一分 解法の有用性を示し、その分解法において機器容量の離散性を考慮 し拡張した横山らの一連の研究 ${ }^{12}$ ) や、遺伝的アルゴリズムを機器 構成設計に利用しその有用性を示した藤田らの研究 ${ }^{3)}$ がある。しか しこれらは熱源構成の最適化のみに焦点を当てており、運用計画の 最適化は対象外である。上記 2) の研究では混合整数計画法を用いた
伊東らの一連の研究 ${ }^{4)}$ や遺伝的アルゴリズムを用いた小原らの研究 5)があるが、これらは熱源構成の最適化に関しては行われていない。 最後に、前述 3)の研究には遺伝的アルゴリズムを用いて熱源構成と 運用計画の同時最適化を行った駒村らの研究 ${ }^{6}$ や、その研究の発展 として遺伝的アルゴリズムの利用は熱源構成の最適化のみに限定し、 運用計画の最適化に関しては離散的な負荷率の組み合わせを総当た りで行った加用らの研究 ${ }^{7)}$ がある。しかし、運用計画の最適化にお いて負荷率が離散的に扱われていることによる最適化の不十分さや 負荷率の組み合わせを総当たりすることによる計算時間の膨大さが 課題となっている。そこで本研究では、年間一次エネルギー消費量 を最適化の目的関数とし、熱源構成の最適化に遺伝的アルゴリズム を、運用計画の最適化にはラグランジュの未定乗数法を用いること で負荷率を連続的に扱い、かつ計算時間の短縮を目指した。更に一 般的なオフィスビルの熱源設計では従来からの経験則で熱源の容量 や運用計画を決定していることもあり、たとえ最適設計がなされて いたとしても実務現場での運用方法が最適とは限らない。そこで本 研究では実務現場での最適設計通りの運用を促寸ために運用計画チ ヤートという新たな表示法を開発した。

\footnotetext{
$*$ 東京大学大学院工学系研究科建築学専攻 大学院生

Graduate Student, Dept. of Architecture, Graduate School of Engineering, The University of Tokyo

** 東京理科大学工学部建築学科 教授·工博

Prof., Dept. of Architecture, Faculty of Engineering, Tokyo University of Science, Dr. Eng.
} 


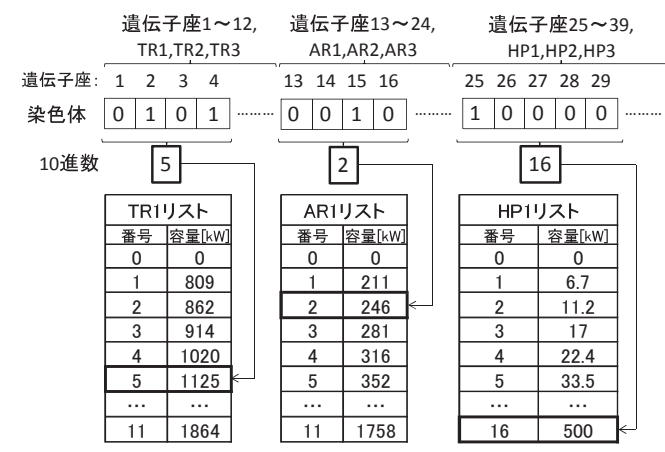

TRとARはそれぞれリスト番号が1〜11である為、2進数では4桁が必要になり。 HPはリスト番号が1〜16である為、2進数では5桁必要になる(表3)

検討ケース(表4)より、3機種とも最大 3 台ずつ考慮する為、 $4 \times 3+4 \times 3+5 \times 3$ の計39の遺伝子長が必要。

図 1 染色体情報と機器容量の関連付忛

\section{2. 最適化手法}

本研究では熱源構成の最適化と運用計画の最適化という 2 つの最 適化を通じて熱源まわり（熱源、一次ポンプ、冷却水ポンプ、冷却塔） の最適化を行った。熱源構成の最適化には単純遺伝的アルゴリズム (SGA) を用いており、各パラメータは個体数 20、遺伝子長 39、交叉 率 0.80 、突然変異率 0.05 を検討ケース全てに共通して用いている。 機器容量の決定方法は、各個体の各遺伝子座に 0 か 1 をランダムに 与え、その染色体情報を機器ラインナップに適用して決定している (図 1)。本研究ではメーカーカタログなどを想定し離散的な機器容 量を平成 21 年度版建築設備設計基準 ${ }^{8)}$ や LCEM ツール ${ }^{9)}$ から参照し ている。また、機器容量に $0 \mathrm{~kW}$ の選択肢を含めることで熱源台数の 最適化にも対応している。運用計画の最適化では稼働可能な熱源の 稼働非稼働を総当たりし、それぞれにラグランジュの未定乗数法に おける等 $\lambda$ 則 100 を適用することで当該組合せの最適負荷配分を決 定する。最終的に一次エネルギー消費量が最も少ない稼働非稼働の 組合せを当該時刻の最適解としている。なお、等 $\lambda$ 則を適用する際 は、負荷率とエネルギー消費率の特性曲線の原関数が 4 次関数以上、 若しくは同特性曲線の導関数が減少する区間を含む場合や不連続の 場合には解の算出が困難であることから、本研究では微小負荷及び 過負荷の場合を除いて特性曲線を 2 次曲線で近似する。一般的な熱 源の特性曲線を鑑みれば、上記のように仮定をおいても十分な汎用 性がある。例として本研究で用いたターボ冷凍機 (以下 TR) と空気熱 源ヒートポンプ (以下 HP) の特性曲線を図 2 左に、図 2 右にはその特 性曲線を出力で一階微分した導関数と上限 (容量)を考慮した際の計 算手順を示す。まず上限がない単純な直線を想定してラグランジュ の未定乗数法により求まる図中の $\lambda$ から出力を算出する (図 2 の出 力 $\mathrm{P}_{\mathrm{Q} 1}$ と出力 $\mathrm{P}_{\mathrm{Q} 2}$ )。その值が機器容量を上回っている場合、值を上限 出力に設定する。図 2 の場合、点 $\mathrm{Q} 2$ の出力 $\mathrm{P}_{\mathrm{Q} 2}$ が機器 $\mathrm{HP}$ の上限出 力 $\mathrm{P}_{\mathrm{HPmax}}$ を超えているため上限出力 $\mathrm{P}_{\mathrm{HP} \text { max }}$ の点 $\mathrm{Q}^{\prime}$ に移動する。出力 を上限值に変化させると合計出力が需要と等しくならないことから、 合計出力が需要より小さければ入を大きくさせ、合計出力が需要よ り大きければ入を小さくすることで需要と等しくなる入を求める。 その手法として本研究では二分法を用いた。図 2 では点Q2から点Q2' に移動したことで不足した HP の出力の分を、 $\lambda$ から $\lambda$ 'に移動する ことで点Q1から点Q1'に移動し出力が増した TR で賄っている。な お、HP も点Q2' から点Q2" に移動するが出力は変わらない。次に需
遺伝子の初期化 $\square$ 遺伝的アルゴリズム関連のプログラム ロラグランジュの未定乗数法関連のプログラム

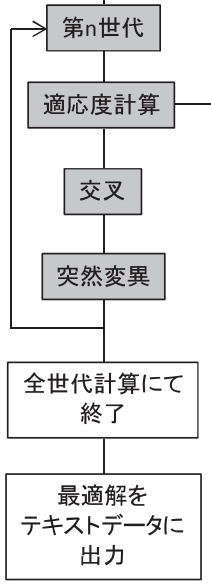

*冷房需要と暖房需 要が混在する中間 期では各機器の冷 暖割り当ては最低 でも1ヶ月間はいず れかの運転を続け させている。

**吸収式冷温水機 においてはその日 の最後の時間を除 いて最低2時間の連 続稼働を義務付け ている。

****各オブジェクトと は3種類の熱源 （タ一ボ冷凍機、吸 収式冷温水機、空 気熱源ヒ一トポン プ)に加えて、一次 ポンプ、ニ次ポンプ、 冷却水ポンプのポン プ類、冷却塔、空調 機の全8種類を指す。

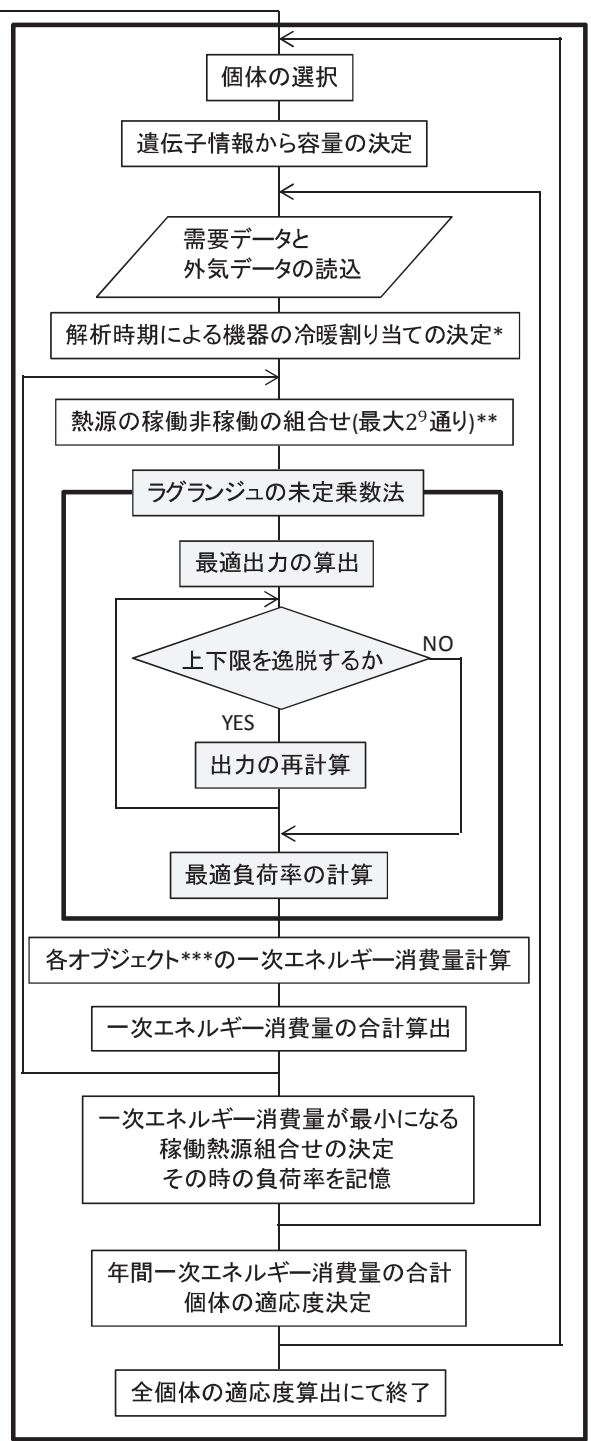

図 3 最適化計算手順 
要が少なく $\lambda$ が図 2 右の $\lambda$ ” の位置の場合を考える。点Q3及び点 $Q 4$ がその稼働非稼働組合せの最適解であるとき、両機器とも垂線に張 付くため TR 及び HP の出力值は一通りに決まらないが、需要が少な いときには機器 1 台のみ稼働している他の稼働非稼働組合せがその 時刻の最適解となるため問題はない。仮に、機器 1 台でも出力が一 通りに決まらないほど微少な需要 (中間期など) の場合は、本研究で は一次エネルギー消費量算出後、垂線上の值の出力を実際の需要に 等しい出力に変更することで当該時刻の最適負荷率を決定している。 本研究で作成した最適化プログラムの計算手順を図 3 に示す。

\section{3. 解析条件と検討ケース}

本研究の解析対象モデルは一般的かつ単純な建物モデルとして 「標準問題の提案」11)を一部変更して用いている。建物概要と基準階 平面図、空調システム図を表 1 、図 4 、図 5 に示す。図 4 は引用元の 図を見やすいように加工している。通年負荷計算は動的熱負荷計算 ソフト「NewHASP/ACLD」 ${ }^{12)}$ により行い、図 4 に示すようにフロアを 東西の事務室、中央の共有スペースに分け、更に事務室は 4 つのゾ

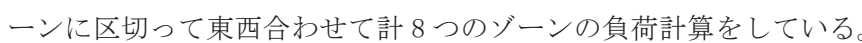
運転条件は表 2 に示したとおりである。計算結果から冷房需要と暖 房需要を別々に集計し、各月の時刻別に平均したものを各月の代表 日の 1 時間ごとの負荷とする。最適化プログラムでは 12 カ月分の 12 代表日 24 時間の計 288 時間分の計算を行う。その後、稼働日数 をかけて各月の一次エネルギー消費量とする。稼働日数は 17 日間 $(9$ 月)、18 日間 (6月)、19 日間 (1, 10 月)、20日間 $(2,4,5,7,11$ 月)、 21 日間 $(12$ 月)、 22 日間 $(3$ 月)、2 23 日間 $(8$ 月)である。一次エネルギー 消費量の計算にて使用した各オブジェクトは前述の設備設計基準 ${ }^{8)}$ 及び LCEM ツール 9) を参照している。オブジェクトは TR、吸収式冷 温水機 (以下 $\mathrm{AR}$ )、HP の 3 種類の熱源と、一次、二次、冷却水の 3 種類のポンプ類、冷却塔、空調機の全 8 種類を用いている。各種熱 源の特性曲線と一次エネルギー基準定格 $\mathrm{COP}$ を図 6 に示す。機器容 量ラインアップを表 3 に示す。

本研究では基準となる一般モデルと、最適化プログラムで計算さ れた最適化モデルを比較することで最適化効果を示す。 2 つのモデ ルには熱源容量と運用計画の両方に違いがある。まず一般モデルの 熱源容量決定方法は、年間の最大冷房需要と最大暖房需要をもとに 表 4 に示寸各ケースで決められた各種機器台数で割り、表 3 に示し た各機器のラインアップの中でその值を賄える最小容量の機器を選 択している。これにより熱源容量はそれぞれの種類ごとに等容量と なる。なお、TR が熱源構成に含まれるケースでは、TR は暖房需要を 賄うことができないことから、まず始めに加熱能力をもった熱源の 台数で暖房需要を割り、加熱能力を持つ熱源の容量を決めた後、そ れらの熱源の合計冷凍能力と最大冷房需要の差を TR の台数で割る ことでTRの容量を決定している。運用計画は、一次エネルギー基準 定格 COP が最も良い熱源を優先的に稼働させ、稼働熱源台数を少な くするために機器 1 台を負荷率 100\%まで稼働させる。機器の最大能 力を超えた場合は一次エネルギー基準定格 COP が良いものから順に 2 台目、3 台目と稼働させる。この時、同種機器を同時稼働させる場 合は等負荷率になるように設定している。一方で最適化モデルの熱 源容量の決定は図 1 に示した方法で行っている。選択された全ての 熱源容量の冷暖能力を足し合わせた值が年間の最大冷暖需要をそれ
表 1 建物概要

\begin{tabular}{|c||c|}
\hline 所在地 & 東京都 \\
\hline 用途 & オフィス \\
\hline 階数 & 地上20階 \\
\hline 構造 & RC造 \\
\hline 延床面積 & $16531.2 \mathrm{~m}^{2}$ \\
\hline 基準階面積 & $826.56 \mathrm{~m}^{2}$ \\
\hline 天井高 & $2.6 \mathrm{~m}$ \\
\hline \multirow{2}{*}{ 空調システム } & VAV方式 \\
\cline { 2 - 3 } & 2次ポンプ変流量方式 \\
\cline { 2 - 3 } & 1次ポンプ定流量方式 \\
\hline
\end{tabular}

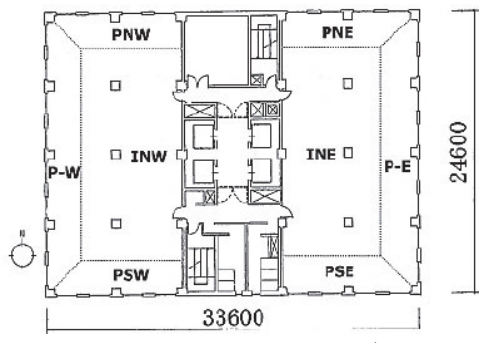

図 4 基準階平面図 ${ }^{11}$

表 2 運転条件

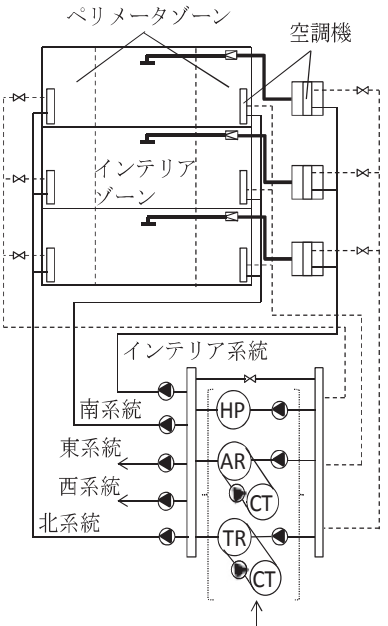

CASEによって熱源選択

図 5 空調システム図

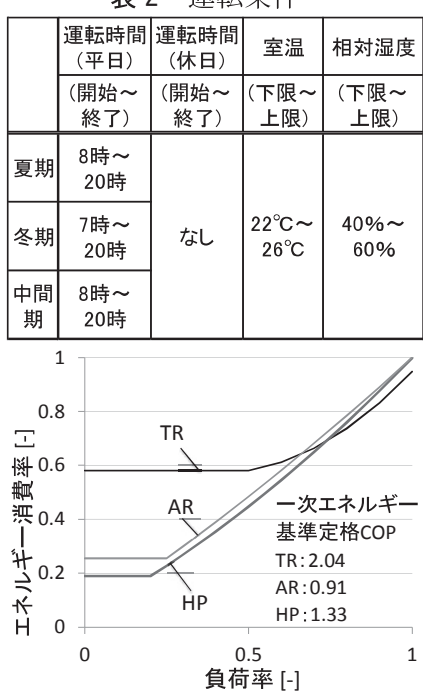

図 6 各種熱源の特性曲線注 1)

表 3 機器容量 $[\mathrm{kW}]$ のラインアップ

\begin{tabular}{|c|c|c|c|c|c|c|c|c|c|c|c|c|c|c|c|c|c|}
\hline \multicolumn{2}{|c|}{ リスス番号 } & 1 & 2 & 3 & 4 & 5 & 6 & 7 & 8 & 9 & 10 & 11 & 12 & 13 & 14 & 15 & 16 \\
\hline \multirow{2}{*}{$\begin{array}{c}\text { ターボ } \\
\text { 冷凍機 } \\
\text { (TR) }\end{array}$} & & 809 & 862 & 914 & 1020 & $1125 \mid 1$ & 1231 & 1301 & 1442 & $1582 \mid 1$ & 1758 & 1864 & & & & & \\
\hline & $\begin{array}{l}\text { 加熱 } \\
\text { 能力 }\end{array}$ & 0 & 0 & 0 & 0 & 0 & 0 & 0 & 0 & 0 & 0 & 0 & & & & & \\
\hline \multirow{2}{*}{$\begin{array}{c}\text { 吸収式 } \\
\text { 冷温水 } \\
\text { 機 } \\
\text { (AR) }\end{array}$} & & 211 & 246 & 281 & 316 & \begin{tabular}{|l|}
352 \\
\end{tabular} & 422 & 527 & 703 & $1055 \mid 1$ & 1407 & 1758 & & & & & \\
\hline & $\begin{array}{l}\text { 加熱 } \\
\text { 能力 }\end{array}$ & 165 & 193 & 220 & 248 & \begin{tabular}{|l|}
277 \\
\end{tabular} & 340 & 425 & 555 & 835 & 1113 & 1393 & & & & & \\
\hline \multirow{2}{*}{$\begin{array}{l}\text { 空気熱 } \\
\text { 源七- } \\
\text { トポン } \\
\text { プ(HP) }\end{array}$} & $\begin{array}{l}\text { 冷凍 } \\
\text { 能力 }\end{array}$ & 6.7 & 11.2 & 17 & 22.4 & 33.5 & 45 & 67 & 106 & 132 & 160 & 212 & 265 & 315 & 375 & 425 & 500 \\
\hline & $\begin{array}{l}\text { 加熱 } \\
\text { 能力 }\end{array}$ & 7.1 & $\mid 11.8$ & 18 & 23.6 & $\mid 35.5$ & 47.5 & 71 & 112 & \begin{tabular}{|l|}
140 \\
\end{tabular} & 170 & 224 & 280 & 315 & 425 & 475 & 560 \\
\hline
\end{tabular}

ターボ冷凍機(TR)の容量はLCEMツールの「遠心冷凍機(インパータ) RC-XX3-3031(06)245 」と「遠心泠凍機(高効率ーインバータ) RC-XX3-3031(10) 230-530」を参照。

吸収式冷温水機(AR)の容量は建築設備設計基準p.334の直焚き吸收冷温水機の諸元 (二重効用)を参照。

空気熱源ヒートポンプ(HP)の容量は建筑設備設計基準 p.331の空気、熱源ヒートポンプ ユニットの諸元を参照

表 4 検討ケース一覽注 2)

\begin{tabular}{|c|c|c|c|}
\hline 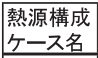 & $\begin{array}{l}\text { モデル別 } \\
\text { ケース名 } \\
\end{array}$ & モデル & 熱源構成 \\
\hline \multirow{2}{*}{ Case 1} & Case1-1 & 一般 & \multirow{2}{*}{ AR2 } \\
\hline & Case1-2 & 最適化 & \\
\hline \multirow{2}{*}{ Case2 } & Case2-1 & 一般 & \multirow{2}{*}{ AR3 } \\
\hline & Case2-2 & 最適化 & \\
\hline \multirow{2}{*}{ Case3 } & Case3-1 & 一般 & \multirow{2}{*}{ TR2AR2 } \\
\hline & Case3-2 & 最適化 & \\
\hline \multirow{2}{*}{ Case4 } & Case4-1 & 一般 & \multirow{2}{*}{ TR3AR3 } \\
\hline & Case4-2 & 最適化 & \\
\hline \multirow{2}{*}{ Case5 } & Case5-1 & 一般 & \multirow{2}{*}{ AR2HP2 } \\
\hline & Case5-2 & 最適化 & \\
\hline \multirow{2}{*}{ Case6 } & Case6-1 & 一般 & \multirow{2}{*}{ AR3HP3 } \\
\hline & Case6-2 & 最適化 & \\
\hline \multirow{2}{*}{ Case7 } & Case7-1 & 一般 & \multirow{2}{*}{ TR3HP3 } \\
\hline & Case 7-2 & 最適化 & \\
\hline \multirow{2}{*}{ Case8 } & Case8-1 & 一般 & \multirow{2}{*}{ TR2AR2HP2 } \\
\hline & Case8-2 & 最適化 & \\
\hline \multirow[t]{2}{*}{ Case9 } & Case9-1 & 一般 & \multirow[t]{2}{*}{ TR3AR3HP3 } \\
\hline & Case9-2 & 最適化 & \\
\hline
\end{tabular}

表 5 Case7 の選択容量 $[\mathrm{kW}]$

\begin{tabular}{|l|l||r|r|}
\cline { 2 - 3 } \multicolumn{2}{c|}{} & \multicolumn{1}{c|}{ Case7-1 } & Case7-2 \\
\hline \multirow{2}{*}{ TR1 } & $\mathrm{C}$ & 809 & 1020 \\
\cline { 2 - 4 } TR2 & $\mathrm{H}$ & 0 & 0 \\
\cline { 2 - 4 } & $\mathrm{H}$ & 809 & 1864 \\
\hline \multirow{2}{*}{ TR3 } & $\mathrm{C}$ & 0 & 0 \\
\cline { 2 - 4 } & $\mathrm{H}$ & 809 & 809 \\
\hline \multirow{2}{*}{ HP1 } & $\mathrm{C}$ & 375 & 500 \\
\cline { 2 - 4 } & $\mathrm{H}$ & 425 & 560 \\
\hline \multirow{2}{*}{ HP2 } & $\mathrm{C}$ & 375 & 212 \\
\cline { 2 - 4 } & $\mathrm{H}$ & 425 & 224 \\
\hline \multirow{2}{*}{ HP3 } & $\mathrm{C}$ & 375 & 425 \\
\cline { 2 - 4 } & $\mathrm{H}$ & 425 & 475 \\
\hline
\end{tabular}

$\mathrm{C}$ は定格冷凍能力、 $\mathrm{H}$ は定格加熱能力 を示す。 
ぞれ賄うことができる場合にのみ、その後の計算をする。運用計画 は図 2 に示したラグランジュの未定乗数法によって算出された出力 を適用している。最適化計算の検討ケースは、熱源構成による最適 化効果の傾向を示すため 9 つの熱源構成を用意してケースごとに一 般モデルと最適化モデルを解析し比較している。それら検討ケース 一覧を表 4 に示す。本研究では熱源構成による年間一次エネルギー 消費量の差を生じさせないようにするため一般モデルと最適化モデ ルを比較する際には同じ熱源構成のものを比較対象にしている。

\section{4. 最適化結果}

\section{1. 計算の高速化}

本研究では前述の既往研究 7)で行われていた離散的な負荷率の総 当たりによる計算をCase2 について行った。GA の個体数を 20 に設 定し負荷率は $1 \%$ 刻みの総当たりで計算したところ、結果が十分収束 寸るまでに 66 時間かかった。しかし本研究の最適化手法を実装した プログラムでは連続した負荷率で計算することができ、かつ計算時 間は 55 秒へと大幅短縮した。計算時間が $1 / 4320$ に短縮したことで 機器数が多いCase3〜Case9 のシミュレーションも可能になり、遺伝 的アルゴリズムの世代数を増やすことも可能になった。

\section{2. 全ヶースの最適化結果}

表 4 に示した検討ケース全ての熱源まわり（熱源、一次ポンプ、冷 却水ポンプ、冷却塔)の年間一次エネルギー消費量を図 7 に示寸。本 研究では二次ポンプ以降の二次側オブジェクトは最適化対象外であ ることから最適化結果の考察は熱源まわりの一次エネルギー消費量 を対象とする。図 7 に示した全ケース中、熱源構成に TR と HP を含 むケース (Case7, 8, 9) で削減効果が高い傾向にある。そこで図 8 に上 記 3 ケースの月間削減率を示す。月別の最適化効果の傾向として中 間期 (4, 5, 10, 11 月) の削減率が特に高く、次いで夏期の 8 月の削減 率が高い。そこで代表的なケースとして Case7 の両モデルを引き合 いに最適化効果の要因を考察する。両モデルの機器容量を表 5 に示 す。ここでまず Case7-1 と Case7-2 に加えて熱源容量・台数のみを GA で最適化し運用計画は一般モデルの手法を用いた Case7-1-1 と、 運用計画のみを機器の稼働非稼働組合せとラグランジュの未定乗数 法で最適化し、熱源容量・台数は一般モデルの手法を用いた Case7-1-2 の全 4 ケースの熱源まわりの年間一次エネルギー消費量 を図 9 に示す。年間削減率はそれぞれを独立で最適化したCase7-1-1 と Case7-1-2 よりもCase7-2 の方が高く、Case7-1-1 と Case7-1-2 を単純に足し合わせた值よりもCase7-2 の方が若干高い削減効果を 示している。

\section{3. 稼働時負荷率の頻度と最適化効果}

次に各月について考察する。始めに削減率が特に高かった中間期 の代表月として 4 月の運用計画を図 10 に示す。Case7-1 では図 10 左に示した割当で稼働させている。一般モデルでは TR1 は容量が大 きくても定格 COP が良いことから優先して稼働されるが低負荷率で の運転が連続しエネルギー消費量が多くなる。一方で Case7-2 では 図 10 右に示したように需要の大小に対応した容量の熱源を稼働さ せている。続いて、中間期の次に削減効果が高かった夏期の 8 月の 運用計画を図 11 に示す。Case7-1では 1 台あたりの容量に対して需 要が大きいため TR1 と TR2 を同時運転させている時間が長いが、 Case7-2 では様々な容量の熱源を需要の大小に応じて稼働させてお

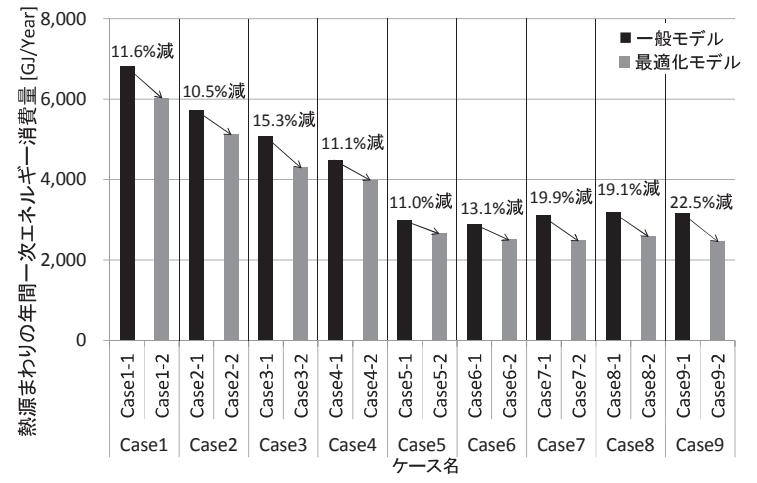

図 7 全ケースの最適化結果

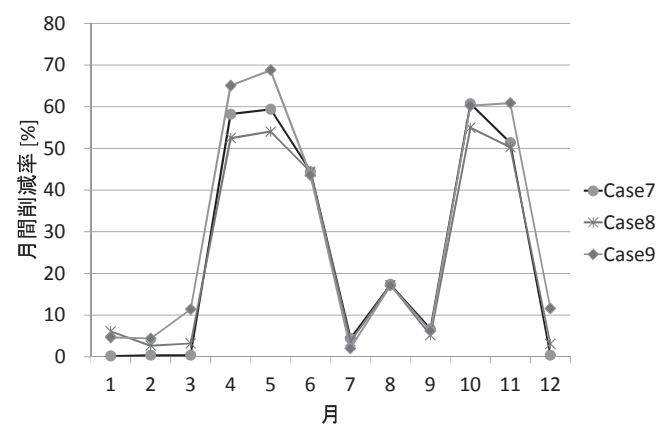

図 8 TR と HP を含むケースの月間削減率

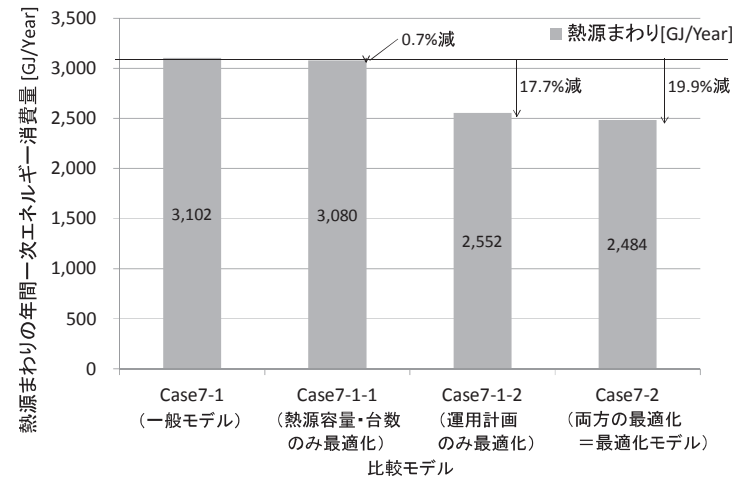

図 9 最適化対象別による削減効果

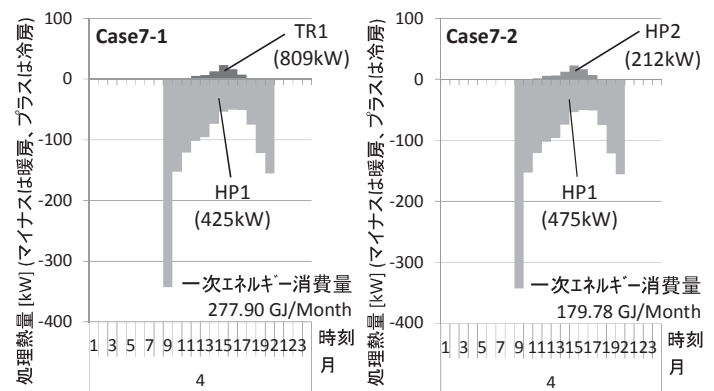

図 104 月の運用計画 (カッコ内は機器容量)

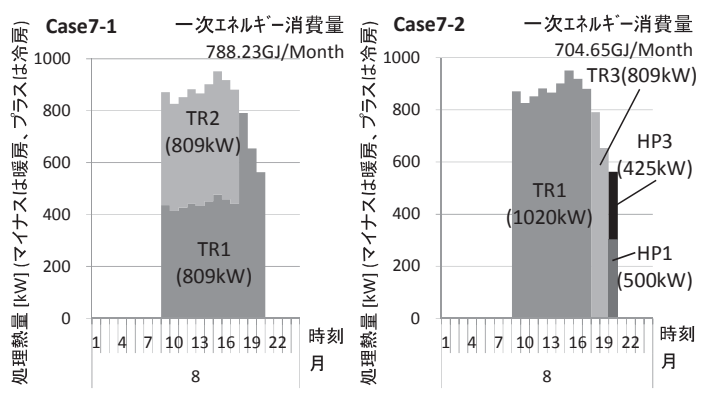

図118月の運用計画 (カッコ内は機器容量) 


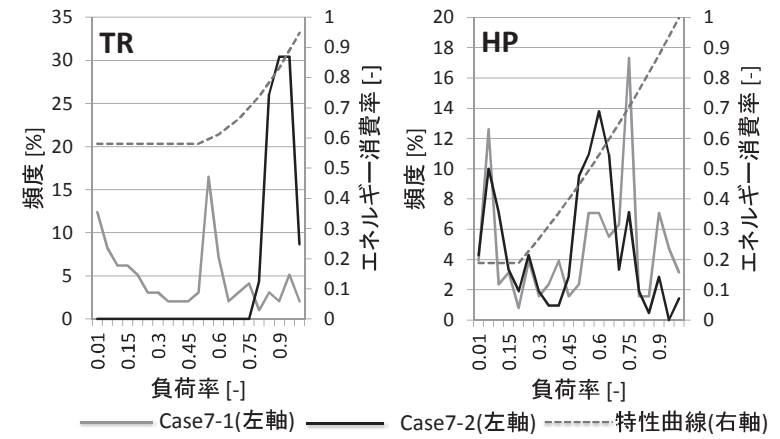

図 12 稼働時負荷率の通年頻度 (左：TR、右：HP) 注 1 )

り、TR が同時稼働している時刻はない。この結果から最適化によっ て図 6 に示した特性曲線上の効率が良い負荷率周辺で運転が行われ ていることが推察される。そこで通年の稼働時負荷率の頻度 [\%] 図 12 に示す。まず、図 12 左の TR では、Case7-1 において一次エネル ギー基準定格 COP が良いことから優先的に稼働させているため $1 \%$ ら40\%までの低負荷運転が多い。一方で、最適化モデルの Case7-2 では低負荷率域の稼働はなく $75 \%$ 以上でのみ稼働している。次に図 12 右の HP は、低負荷率域において Case7-1 と Case7-2 の頻度は同 程度であるが、容量が大きい TR を低負荷率域で稼働させている Case7-1 と比べて結果的に一次エネルギー消費量は少なくなってい る。更に図 6 の特性曲線において効率の良い負荷率 50\%から $60 \%$ 付近 での稼働が多くなっている。以上より、容量を不等分割した熱源を 需要の大小に応じて適切に切り替えることが最適化効果を高めてお り、この結果は熱源の容量・台数と運用計画の総合的な最適化が有 効であることを示している。

\section{5. 同種熱源の最適負荷配分}

実際の運用現場では同種熱源を同時稼働させる場合、制御上の理 由から同負荷率で稼働させることが多い。しかしラグランジュの未 定乗数法を用いれば同様のことが省エネの観点からも容易に証明で きる。以下で数式を用いて示す。まず、ラグランジュの未定乗数法 を適用するための条件として定格 $\mathrm{COP}$ と図 6 に示した負荷率とエネ ルギー消費率で表した特性曲線が等しいことに加えて、その特性曲 線の導関数が連続、かつ単調増加であることが必要である。今、上 記の条件を満たす同種の熱源が複数台あるとする。この時、 $i$ 台目の 熱源のエネルギー消費率が式(1)の 2 次関数で表されるとする。なお、 特性曲線が等しいことから係数 $A, B, C$ は機器によらず同一である。

$$
R_{i}=A \times L_{i}{ }^{2}+B \times L_{i}+C
$$

この時 $R_{i}$ はエネルギー消費率 $[-] 、 L_{i}$ は負荷率 $[-]$ とする。この特 性曲線の負荷率 $L_{i}$ を定格出力 $R P_{i}$ と出力 $P_{i}$ を用いて表し、両辺に定格 消費電力 $R E_{i}[\mathrm{~kW}]$ をかけると、式 (2) に示すように電力消費量 $E_{i}$ $[\mathrm{kW}]$ と出力 $P_{i}[\mathrm{~kW}]$ の関係式になる。

$$
E_{i}=A \times R E_{i} \times\left(P_{i} / R P_{i}\right)^{2}+B \times R E_{i} \times\left(P_{i} / R P_{i}\right)+C \times R E_{i}
$$

等 $\lambda$ 則 ${ }^{10)}$ より、式(2) を出力 $P_{i}$ で微分した導関数が、全ての機器 で等しいときに最適解となることからラグランジュ乗数入を用いて 下式が成り立つ。

$$
\lambda=2 A \times R E_{i} / R P_{i} \times\left(P_{i} / R P_{i}\right)+B \times R E_{i} / R P_{i}
$$

今、定格 $\mathrm{COP}$ と特性曲線が等しいため以下の関係が成り立つ。

$$
R P_{i} / R E_{i}=\operatorname{COP}(\text { 一定 }) \quad(4) \Leftrightarrow R E_{i} / R P_{i}=1 / \operatorname{COP}(\text { 一定 })
$$

式(5)を式(3)に代入すると式(6)が成り立つ。

$$
\lambda=2 \mathrm{~A} \times P_{i} /\left(C O P \times R P_{i}\right)+B / C O P
$$

ここで式(6)の出力表示を負荷率表示に戻すと式 (7)が成り立つ。

$$
\lambda=2 \mathrm{~A} \times L_{i} / C O P+B / C O P
$$

式(7)より入を等しくするためには唯一の変数である負荷率 $L_{i}$ を 等しくすることが条件であることがわかる。以上から、同種熱源の 同時稼働時は同負荷率で稼働させた時がもっとも省エネになること が明らかになり、今後運用計画の最適化に関する研究において前述 の条件を満たしていれば最適化計算を行うことなく最適負荷配分を 決定することができる。

\section{6. 運用計画チャートの開発}

\section{1. 運用計画チャートの意義}

実務現場では設計者の意図とは異なる形で運用されている可能性 があることから、最適化による結果の実行を促進するために、より 便利な運用計画表を作ることが必要であると考えた。そこで本研究 では運用計画チャートと称して新たな表示法を開発した。

\section{2. 詳細版運用計画チャート}

本研究で開発する運用計画チャートは、「需要がいくつの時に」、 「どの熱源機器を」、「いくらの出力で」稼働させるのかを一目瞭然 にすることで実務において容易に熱源を最適運用することのアシス 卜を目指している。そのために今回各機器の出力を縦軸に、需要を 横軸に設定したチャートを考案した。運用計画チャートは冬期、夏 期と中間期 4 力月分の合計 6 種類を作成する。これは冬期及び夏期 についてはその期間中、各機器は暖房もしくは冷房を専用に稼働し ていることから冬期用と夏期用の 2 種類の運用計画チャートで問題 ないが、中間期では各機器は 1 ケ月の間冷房もしくは暖房のいずれ か片方を専用に稼働するように設定していることから、同じ機器で も中間期の 4 カ月間でみると冷房と暖房の両方に割り当てられてい る可能性がある。例えば、冷暖両方の能力をもつ HP や AR では HP1 台目は、4月は暖房で 5 月は冷房に割り当てられ、HP2 台目はその逆 といった可能性がある。その場合、4 月5 月を緾めて運用計画チャ 一トに表示すると冷房と暖房の両方に同じ熱源が存在することにな り混乱を招くおそれがある。そこで中間期は 4 个月分別々の運用計 画チャートを 4 種類作成することで対応している。

本研究では最適化結果を忠実に表現したものを詳細版運用計画于 ヤートと称する。この運用計画チャートは最適化計算で算出された 各機器の最適容量を基に、最適化プログラムとは別のチャート作成 プログラムで計算することで出力の解を算出し、図にプロットし線 分で結んで作成している。そのチャート作成プログラムは、最適化 計算における与条件の需要と外気温をグラフにプロットし、冷房需 要及び暖房需要それぞれの 3 次近似曲線をとった上で(図 13)、外気

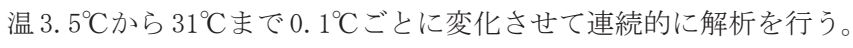
図 13 では両近似曲線とも縦軸のプラス域からマイナス域にまたが っているが、解析の際は縦軸のマイナス域は暖房需要の近似曲線を、 プラス域は冷房需要の近似曲線の值を用いている。詳細版運用計画 チャートの代表的なものとして Case7-2 の冬期の詳細版運用計画チ ヤートを図 14 上に示す。

\section{3. 簡易版運用計画チャート}

詳細版運用計画チャート通り運用すれば最も省エネになるが、場 


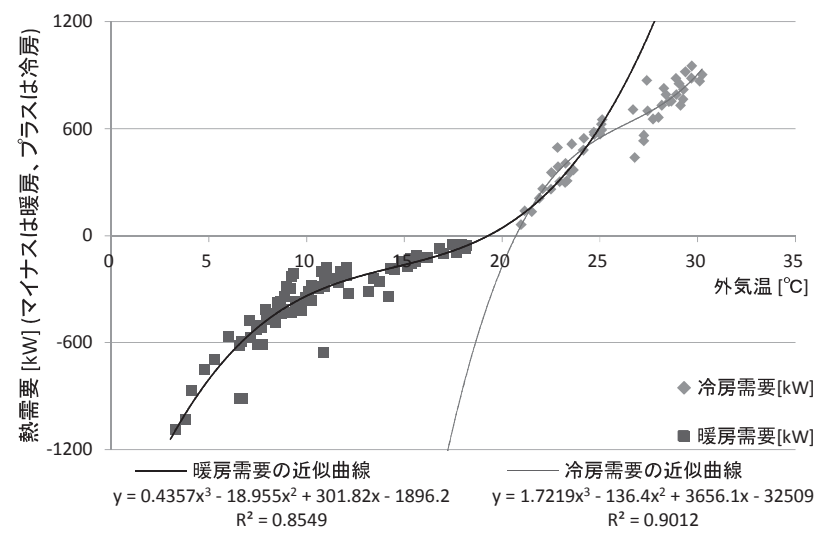

図 13 チャート作成プログラムにおける需要と外気温の与条件

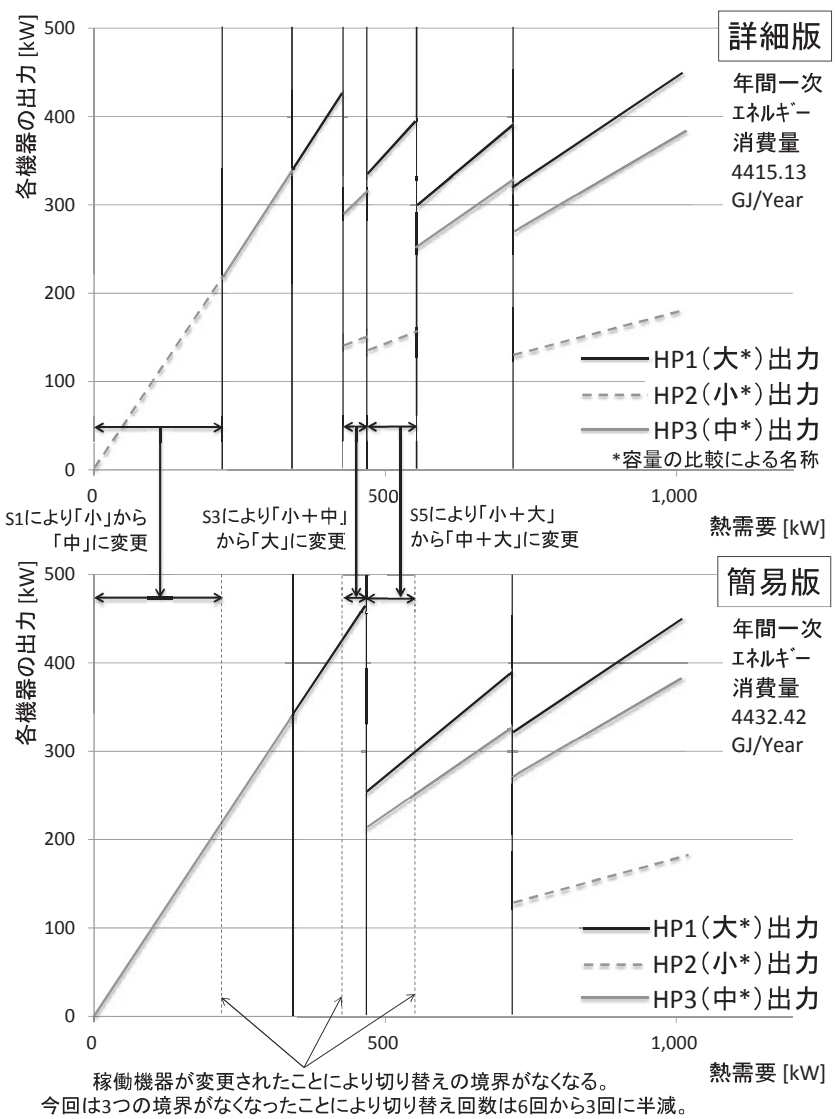

今回は3つの境界がかくなったことにこより切り替え回数は6回から3回に半澸。

図 14 詳細版 (上図)、簡易版 (下図)の冬期運用計画チャート

合によっては機器の切り替え回数が多く、運用が複雑になるケース も想定される。そこで最適解の他に機器の切り替え回数を減らした 簡易版運用計画チャートの開発を試みた。代表的なものとして図 14 下に Case7-2 の冬期の簡易版運用計画チャートを示す。この図 14 の上下両図は詳細版と簡易版の対応関係になっている。この簡易版 運用計画チャートの作成手順を図 15 に示す。まず遺伝的アルゴリズ ムとラグランジュの未定乗数法を用いた最適化計算によって熱源の 最適容量を決定する。その容量を基にもう一度運用計画の最適化を 行うが、その際、まず簡易化スイッチ(表 6) という 0,1 の変数 (0 が スイッチ 0 FF、 1 がスイッチ $0 \mathrm{~N})$ を用意しこの組合せを総当たりで計 算する。ただしスイッチ 3,4 及びスイッチ 8,9 の組合せは変更前の

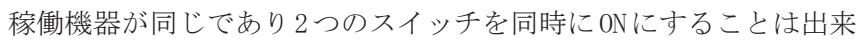

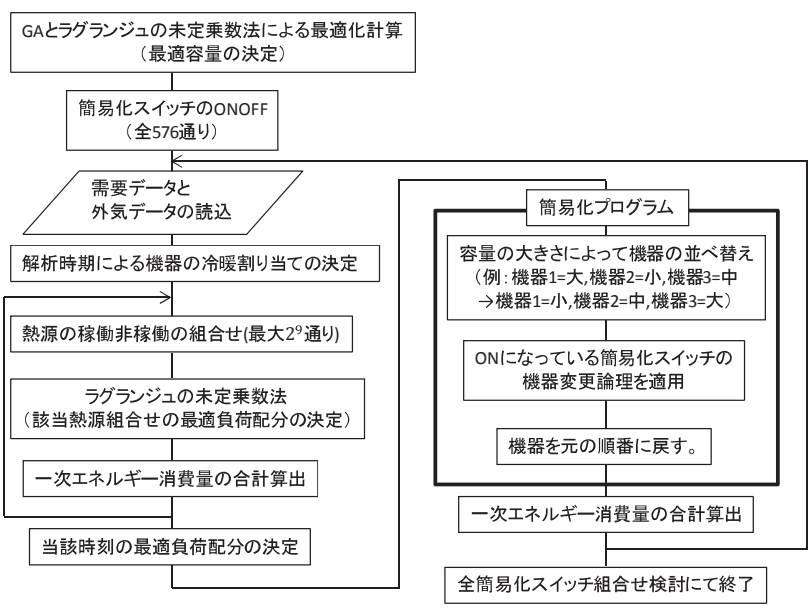

図 15 簡易化プログラムの計算手順

表 6 簡易化スイッチと機器変更論理

\begin{tabular}{|c|c|c|c|c|}
\hline & $\begin{array}{c}\text { 簡易化スイツチ } \\
(0=\text { 非稼動, } 1=\text { 稼働) }\end{array}$ & 変更前 & 変更後 & \multirow{11}{*}{ 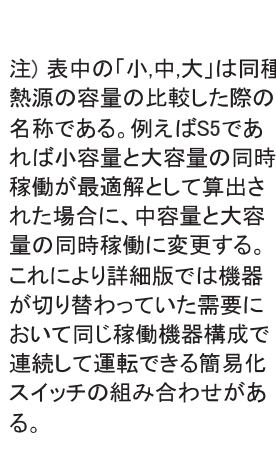 } \\
\hline \multirow{5}{*}{ 冷房時 } & $S 1(=0,1)$ & 小 & 中 & \\
\hline & $\mathrm{S} 2(=0,1)$ & 中 & 大 & \\
\hline & $\mathrm{S} 3(=0,1)$ & 小+中 & 大 & \\
\hline & $\mathrm{S} 4(=0,1)$ & 小+中 & 中+大 & \\
\hline & $\mathrm{S} 5(=0,1)$ & 小+大 & 中+大 & \\
\hline \multirow{5}{*}{ 暖房時 } & $\mathrm{S}_{6}(=0,1)$ & 小 & 中 & \\
\hline & $S 7(=0,1)$ & 中 & 大 & \\
\hline & $\mathrm{S} 8(=0,1)$ & 小+中 & 大 & \\
\hline & $S 9(=0,1)$ & 小+中 & 中+大 & \\
\hline & $\mathrm{S} 10(=0,1)$ & 小+大 & 中+大 & \\
\hline
\end{tabular}
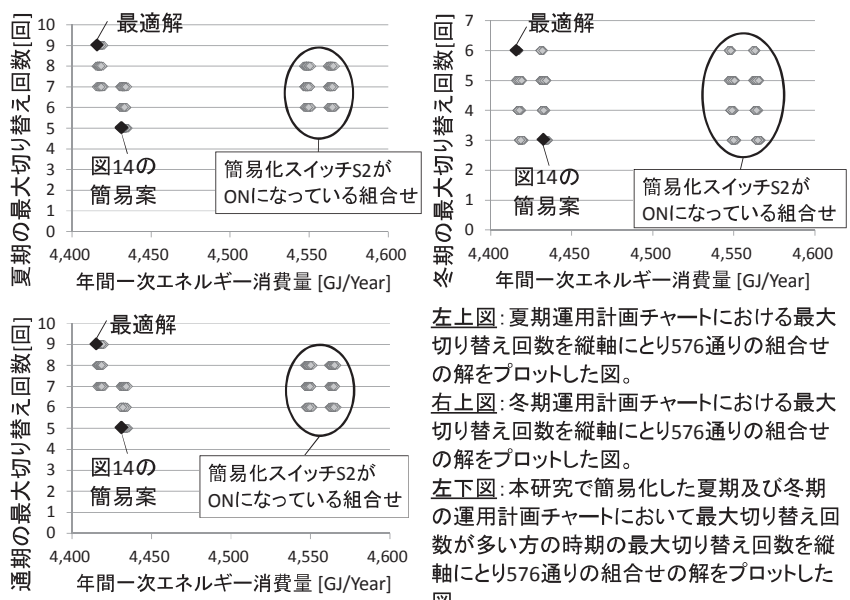

左上図:夏期運用計画チャートにおける最大 切り替え回数を縌軸にとり576通りの組合せ の解をプロットした図。

右上図: 冬期運用計画チャートにおける最大 切り替え回数を綖軸にとり576通りの組合せ の解をプロットした図。

左下図: 本研究で簡易化した夏期及び冬期 の運用計画チャートにおいて最大切り替え回 数が多い方の時期の最大切り替え回数を縦 軸にとり576通りの組合せの解をプロットした

図 16 簡易化スイッチ 576 通りのプロット図

ないことから除外しているため、全部で 576 通りの計算をしている。

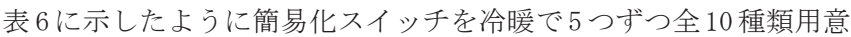
することで冷房と暖房で異なる簡易化を行えるようにしている。表 6 の簡易化スイッチの変更前及び変更後に書かれている「小」、「中、 「大」とは同種熱源において定格能力を比較した際の名称である。例 えば、最適解で HP1、HP2、HP3 の定格冷凍能力がそれぞれ $500 \mathrm{~kW} 、$ $212 \mathrm{~kW} 、 425 \mathrm{~kW}$ と選択された場合、簡易化プログラムによる各機器の 名称はHP1 が「大」、HP2 が「小」HP3 が「中」になる。そこで例え 
ば簡易化スイッチ S5 が 0N の場合、「小十大」の組合せ、つまり HP2 と HP1の組合せを、「中十大」つまり HP3 と HP1 の組合せに変更して 負荷配分を再計算する。このようにすることで図 14 に示したように 機器切り替え回数を減らしている。なお、図 14 下の簡易版はスイッ チ S1, S3, S5, S6, S8, S10 が ON の組合せの簡易案を運用計画チャート に示した結果である。簡易化は同種機器が 3 台以上想定されている ケースで、かつ冬期及び夏期にしか行っていない。これは例えば、 同種熱源が 2 台であった場合、稼働機器組合せがある程度絞られる ことから運用計画チャートは複雑にはならず、中間期は需要自体が 少ないことから運用計画チャートが複雑にならないため簡易化の対 象外とした。上記の計算により求めた解 576 個のプロットを図 16 の各図に示す。簡易化の結果を考察するにあたって焦点となるのが、 機器の最大切り替え回数と年間一次エネルギー消費量であることか ら図 16 の各図は縦軸に機器の最大切り替え回数を、横軸に年間一次 エネルギー消費量をとっている。最大切り替え回数は簡易化が施さ れた夏期と冬期の 2 つ分あることから図 16 には夏期の最大切り替え 回数を縦軸にとった左上図と、冬期の最大切り替え回数を縦軸にと った右上図、そして通期で夕た場合の最大切り替え回数を縦軸にと った左下図を示した。夏期と冬期では切り替え回数の減少が異なる ため 2 種類の図を示した。今回取り上げた Case 7 では夏期の最大切 り替え回数が冬期と比べて二倍近く多いため通期でみた左下図は夏 期の左上図とほぼ等しくなっている。最適解は機器の最大切り替え 回数が最も多いが年間一次エネルギー消費量は最も小さく、簡易案 は機器の最大切り替え回数を減らす意図で計算されているため機器 の最大切り替え回数は最適解より減る可能性があるが、年間一次エ ネルギー消費量は最適解と比べて増加寸る。このことより図 16 の各 図において最適解は一番左上に位置している。

図 16 の各図において年間一次エネルギー消費量が $4550 \mathrm{~kW}$ 付近に 6 つ若しくは 8 つの点に集中している群がある。これらは簡易化ス イッチ S2 が ON になっている組合せの解である。 S 2 は夏期において 中容量の機器を大容量に変更するものであるが、横軸の $4550 \mathrm{~kW}$ 付近 に解の群ができたのは、TRの稼働機器変更の影響を強く受けた結果 である。表 5 に示したように TRにおける名称の「中」と「大」は、 中容量 $(1020 \mathrm{~kW})$ の TR1、大容量 $(1864 \mathrm{~kW})$ の TR2 であり、容量にして 1.83 倍の差がある。一方で同じ S2 の影響を受けた HP は中容量 (425kW) の HP3、大容量 $(500 \mathrm{~kW})$ の HP1 でありその差は 1.17 倍に留ま っている。容量が大きくなればその分一次エネルギー消費量も増加 するため、結果として機器変更による容量の変化が小さいHP の影響 はほとんどなく、TRの機器変更による影響を強く受けたのは明らか である。

図 14 下の簡易化によって、年間一次エネルギー消費量の増加を $0.04 \%$ に抑えつつ冬期の切り替え回数を 6 回から 3 回に半減させ、夏 期は 9 回から 5 回に減少させることができた。これによって最適解 の他にも機器の切り替え回数を減らした案など複数案提示すること で幅広い選択肢を提供することができるようになった。なお、通年 でみた場合の機器の最大切り替え回数は全需要を計算した後で明ら かになるものであるため、パレート解算出時に良く用いられる、い ずれか片方の目的関数をある值に制限してもう一方を最適化すると いう計算手法は困難であった。そのため本研究では総当たりで計算 した。

\section{7. まとめ}

本研究では、熱源容量・台数の最適化に既往研究で用いられてい た遺伝的アルゴリズムを、運用計画の最適化にはラグランジュの未 定乗数法を適用することで、既往研究で用いられていた手法と比べ 効率よく最適化を行う手法を確立した。この高効率化によって運用 計画の最適化にかかる計算時間を大幅に短縮することができるよう になり、その結果多くの熱源が必要と想定されるケースの最適化計 算も可能になった。

次に、実務において最適設計通りの運用を促進するための策とし て運用計画チャートの開発を行った。この開発では最適化結果を反 映させた詳細版運用計画チャートを開発すると同時に、チャートが 複雑になる原因であった機器の切り替え回数を減少させることで利 便性の向上を目指した簡易版運用計画チャートの開発を行った。簡 易化によって年間一次エネルギー消費量の増加を $0.04 \%$ に抑えつつ、 機器の切り替え回数を減少させることに成功した。

今後の課題としてより実務現場に則した運用計画チャートへの改 良や、最適化計算及び運用計画チャートの作成のさらなる高速化が 挙げられる。

\section{参考文献}

1）横山良平・長谷川秦士・伊東弘一：混合整数線形計画法の一分解法によ るエネルギー供給システムの機器構成最適化, 日本機械学会論文集 (C 編), 66 巻 652 号, pp. 204-211, 2000. 12

2）横山良平・森岡純也・伊東弘一: 機器容量の離散性を考慮したエネルギ 一供給システムの機器構成最適化, 日本機械学会第 12 回設計工学・システ ム部門講演会講演論文集, pp. 372-375, 2002. 11

3）藤田喜久雄・赤木新介・廣川敬康・吉田清峰 : 遺伝的アルゴリズムによ るエネルギープラントの機器構成設計法に関する研究, 日本機械学会論文 集 (C 編)， 64 巻 617 号, pp. 354-361，1998.1

4) 伊東弘一：コージェネレーションの最適計画, 産業図書, 1990.4

5）小原伸哉・工藤一彦：遺伝的アルゴリズムによる燃料電池およびヒート ポンプ複合システムの多目的運用計画, 空気調和・衛生工学会論文集, No. 91 , pp. $65-75$, 2003. 10

6）駒村和彦・大岡龍三 : 遺伝的アルゴリズムを用いた都市・建築設備のエ ネルギーシステム最適設計手法の開発，日本建築学会環境系論文集，第 620 号, pp. 43-50, 2007. 10

7）加用現空・大岡龍三 : 遺伝的アルゴリズムを用いた分散エネルギーシス テム最適計画手法の開発 予測精度に及ぼす $\mathrm{GA}$ パラメータの影響検討と分 散エネルギーシステムの効果の確認，日本建築学会環境系論文集，第 74 巻, 第 641 号, pp. 869-876, 2009, 7

8）国土交通省大臣官房官庁営繥部設備・環境課監修: 平成 21 年度版建築設 備設計基準，公共建築協会，全国建設研究センター, pp. 326-407, 2009

9）国土交通省大臣官房官庁営繥部：LCEM ツールVer3.03，2011.3

10）長谷川淳 - 斉藤浩海 · 大山力 $\cdot$ 北裕幸 $\cdot$ 三谷康範 : 電気学会大学講座電 力制御工学, pp. 89-99, 電気学会, 2002.3

11) 滝沢博: 標準問題の提案 (オフィス用標準問題), 日本建築学会環境工学 委員会, 熱シンポジウム, pp. 35-42, 1985.7

12）空気調和 - 衛生工学会, 空気調和設備委員会: NewHASP/ACLD (Ver. 2009117)，2008. 10

\section{注}

注 1)ここに示した特性曲線は冷房時の特性曲線を示している。TR は利絵客翠 入り口温度が $32^{\circ} \mathrm{C}$ 時、HP は外気温が $28^{\circ} \mathrm{C}$ の時である。熱源の冷水出入 口温度は $7^{\circ} \mathrm{C} 、 12^{\circ} \mathrm{C} 、$ 温水出入口温度は $50^{\circ} \mathrm{C} 、 45^{\circ} \mathrm{C}$ に固定している。

注 2) TR はインバータターボ冷凍機、AR は吸収式冷温水機、HP は空気熱源ヒ ートポンプを指す。表内の熱源構成に書かれた AR2 などの表示はAR が 2 台 の熱源構成であることを示している。なお、最適化モデルでは容量 $0 \mathrm{~kW} \mathrm{が}$ 選択される可能性があるため最大台数を意味する。

（2013年 4 月 1 日原稿受理， 2013年 6 月17日採用決定） 